\title{
The Effect of Blended Learning on EFL Learners' Reading Proficiency
}

\author{
Tina Ghazizadeh \\ ELT Department, Roudehen Branch, Islamic Azad University, Roudehen, Iran \\ Hamidreza Fatemipour \\ ELT Department, Roudehen Branch, Islamic Azad University, Roudehen, Iran
}

\begin{abstract}
The present study aimed at determining the effect of blended learning on the reading proficiency of Iranian EFL learners. A quasi-experimental design was adopted to reach this goal. Sixty intermediate-level Iranian EFL learners were randomly assigned to two groups. The control group received conventional classroom instruction in General English, whereas the experimental group received classroom instruction in General English including blended instruction in the reading skill. The blended learning material was developed by the researcher. Both groups were tested for their reading skills before and after the treatment using the reading section of the Preliminary English Test (PET) and their scores were compared through an independent $t$ test. The SPSS software was utilized in order to analyze the data. The results indicated that blended learning has a statistically significant positive effect on the reading proficiency of Iranian EFL learners. Blended learning can be adopted in the English language classes, in order to facilitate the learning process especially that of the reading skill.
\end{abstract}

Index Terms — blended learning, reading proficiency, English as a foreign language

\section{INTRODUCTION}

Reading materials have been considered as one of the primary sources of acquiring comprehensible input and therefore reading has always been a significant aspect of language learning (Chastain, 1988). Since the 1980s, a number of advances have been made in research on reading, both in first and second language contexts. Unlike previous findings which viewed reading as a passive skill, recent findings showed that reading should be considered as an active process. In fact, readers are engaged in high mental activities. Krashen (1988) believes that readers recreate the message while reading. According to Rumelhart (1977), the reader, the text, and the interaction between the reader and the text are involved in reading. In this interactive process of reading, meaningfulness plays a very important role in better comprehension of the text. Since the 1960s, most cognitive psychologists have focused on the role of meaningful learning and the organization of background knowledge.

Unfortunately many second or foreign language learners do not know how to handle the process of reading and therefore they have problems in comprehending the texts, and this causes lack of interest in reading and thus creates quite a problem for the system of education. As mentioned earlier, the reading skill is of utmost importance and it is an important source of comprehensible input in language learning. Therefore it is the role of the language teachers and educational planners to devise appropriate tasks to improve this skill among language learners inside and outside of the language learning classroom.

In the Iranian system of education, traditional methods such as Grammar Translation Method have been used for a long time. The major focus of this method is on the reading skill, as well as grammar and vocabulary. Although reading is one of the essential academic skills strongly required later in the students' academic life, and it is focused upon in language education at school, the students face problems while reading at university level. Perhaps the adoption of traditional methods in reading instruction could be the source of this problem.

According to Thorne (2003), blended learning is the most logical and natural evolution of our learning agenda. It suggests an elegant solution to the challenges of tailoring learning and development to the needs of individuals. It represents an opportunity to integrate the innovative and technological advances offered by online learning with the interaction and participation offered in the best of traditional learning" (p. 2). He adds that, "blended learning represents a very real step towards doing it differently and providing schools, colleges and corporate organizations with a real opportunity to make progress either in ways of working, the environment, or in giving individuals freedom to be themselves" (p. 20).

Since reading proficiency is one of the important tools for acquiring foreign language input, the application of blended learning in this skill would be of great help to Iranian students. Unfortunately, old methods of teaching reading are still applied in our educational system and many Iranian teachers are not completely aware of this fairly new trend in language teaching. Despite the load of research carried out on this issue, few studies have been done on the application of different task types of reading proficiency on Iranian EFL learners. 
Regarding the problems mentioned above, and the novelty of blended learning in the Iranian system of education, it is worthwhile putting the new concept to test in terms of its effectiveness for improving the reading proficiency of Iranian EFL learners. Therefore, the purpose of the present study is to investigate the effect of blended learning on the reading proficiency of Iranian EFL learners.

Regarding the high demand on English reading in the academic world, it is necessary for Iranian EFL learners to improve their reading skills and thus have better comprehension of English texts. If learners become familiar with appropriate reading techniques, they will become more motivated to read more and this leads to a tendency to more exposure to input in the foreign language. According to Krashen (1988), one of the many ways of learning a language is by being exposed to sufficient input, and reading is considered as one of the receptive skills and a good source of acquiring input.

This research study aims at investigating the following research question:

Q: Does blended learning have a statistically significant effect on Iranian EFL learners' reading proficiency?

The hypothetical answer, i.e., null hypothesis to the above question is:

H0. Blended learning does not have any statistically significant effect on Iranian EFL learners' reading proficiency.

\section{LITERATURE REVIEW}

\section{A. Blended Learning}

Defining hybrid or blended education is a more complex task than one might imagine. Different scholars have widely differing opinions on the issue. One definition provided by McGee and Reis (2012) considers hybrid courses as those that "involve instructor and learners working together in mixed delivery modes, typically face-to-face and technology mediated, to accomplish learning outcomes that are pedagogically supported through assignments, activities, and assessments as appropriate for a given mode and which bridge course environments in a manner meaningful to the learner" (p. 9). This indicates that in blended learning, online technology is not only a supplement but a core part of the program. That does not mean a teacher can simply start a chat room or upload lecture videos and say he is leading a hybrid classroom.

Osguthorpe and Graham (2003) define blended learning in three main themes, i.e., combining instructional modalities, combining instructional methods and combining online and face to face instructions. The first two positions debate the influences of media versus method on learning. According to them, both of these positions defined blended learning so broadly that they encompass virtually all learning systems. In other words, it would be hard to find a system that did not involve multiple instructional methods and multiple delivery media. So using these two definitions cannot convey the meaning of blended learning. The third position is the most accurate one and it also emphasizes the central role of computer based technologies in blended learning.

Blended learning is defined simply as a learning environment that combines technology with face-to-face learning. In other words, blended learning means using a variety of delivery methods to best meet the course objectives by combining face-to-face teaching in a traditional classroom including teaching online (Akkoyunlu \& Yilmaz Soylo, 2006). According to Bersin (2003),"blended learning is the combination of different training "media" (technologies, activities, and types of events) to create an optimum training program for a specific audience" (p. Xv).

Graham (2006) postulates that blended learning happens in one of the different levels below:

Activity level: When an activity includes both face to face and computer mediated elements then blending at the activity level occurs.

Course level: Blending at this level is one of the most common ways to blend. Course level blend involves combining distinct face to face and computer mediated activities. Some blended methods involve students in different but supportive face to face and computer mediated activities which are overlapping by the time passing while other methods divide the time into blocks so that they are sequential but not overlapping.

Program level: At the program level, blending often involves one of these two models. In one model, the learners choose a blend between face to face courses and online courses and the other model is a mix between the two which is arranged by the program.

Institutional level: Some of the institutions are committed to blend face to face and computer mediated instruction. Many organizations besides institutions of higher education are making models of blended learning at an institutional level.

Through the levels mentioned above, Graham (2006) maintains that the learner or the designer/teacher determines the nature of the blend. The learner can often choose the blend at the levels of institutional and program. While the blend at the course and an activity level is prescribed by the designer/teacher.

\section{B. Reading Proficiency}

Richards and Schmidt [10] postulated that various types of reading comprehension are often distinguished according to the readers' purposes in reading and the type of reading used. They are commonly referred to as: "literal comprehension which is reading in order to understand, remember, or recall the information explicitly contained in a passage and inferential comprehension that is reading in order to find information which is not explicitly stated in the passage, using the reads experience and intuition, and by inferring” (p. 443). 
Rivers (1968) distinguished two activities which are called reading but must not be confused with each other. A student who stands up in class and enunciates the sounds symbolized by the printed or written marks on the script may be considered to be 'reading', but being trained for this is a minor goal. The students must also learn to derive meaning from the text without necessarily vocalizing what is being read. As Rivers stated this is reading for comprehension.

There are three general approaches to teaching reading in the second or foreign language context; the top-down approach, the bottom-up approach and the interactive approach, which will be thoroughly discussed in the following.

"The top-down approach emphasizes readers bringing meaning to text based on their experiential background and interpreting text based on their prior knowledge (whole language)". The term top is referred to "higher order mental concepts such as the knowledge and expectations of the reader," whereas the word bottom points out to the physical text on the page. This model promotes the reader as an active participant in the reading process and shifts the reader from earlier views of second language reading as a passive linguistic decoder to more contemporary views of second language reading as an active predictor (Goodman, 1988, as cited in Abisamra, 2009, p. 1).

Yet, there are criticisms to the model. Some of the problems mentioned by Stanovich (1980) include the fact that for many texts, the reader might have inconsiderable knowledge of the topic and therefore, be unable to generate predictions. Even in case of skilled readers, Stanovich argues that generating predictions may take longer than it would to recognize the words (as cited in Abisamra, 2009).

The bottom up approach holds that "the meaning of any text must be decoded by the reader and that students are reading when they can sound out words on a page". It emphasizes the ability to decode or put into sound what is seen in a text, i.e., it aligns with the phonic approach to teaching first language reading. "It ignores helping emerging readers to recognize what they, as readers, bring to the information on the page. This model starts with the printed stimuli and works its way up to the higher level stages. The sequence of processing proceeds from the incoming data to higher level encodings" (Stanovich, 1980, as cited in Abisamra, 2009. p. 1).

Some of the criticisms of this model assert that it is difficult to account for sentence-context effects and the role of prior knowledge of text topic as facilitating variables in word recognition and comprehension because of lack of feedback (Stanovich, 1980, as cited in Abisamra, 2009). Furthermore, "it underestimates the contribution of the reader who makes predictions and processes information" (Eskey, as cited in Abisamra, 2009, p. 1).

In the following years, theorists came to believe in the combination of the above mentioned models in order to compensate the weaknesses of one with the other. This model recognizes the importance of both the text and the reader in the reading process, and is referred to as the interactive approach to teaching second language reading (Rumelhart, 1977). Reading is the process of information derived from the text plus the reader's information.

The interactive model stresses both what is on the written page and what a reader brings to it using both top-down and bottom-up processing. It views reading as the interaction between the reader and the text.

The over reliance "on either mode of processing to the neglect of the other mode has been found to cause reading difficulties for learners. The interactive models of reading assume that skills at all levels are interactively available to process and interpret the text" (Grabe, 1988, as cited in Abisamra, 2009, p. 1). "In this model, good readers are both good decoders and good interpreters of text, their decoding skills becoming more automatic but no less important as their reading skill develops" (Eskey, 1988, as cited in Abisamra, 2009, p. 1).

\section{Review of the Related Studies}

Blended learning has been widely studied in its different aspects. In a study by Garcia-Ruiz (2005), the advantages of teaching information management systems with blended learning methods were investigated. They reported that the advantages of Web-based learning combined with traditional learning include all other kinds of technology-based training. Some of these benefits are that the training is usually highly interactive, self-paced, and the rate of the results is increasing.

Shih (2011) used web 2.0 technology, a subdivision of blended learning, to assist college students in learning English writing. The survey results showed that the students were able to improve their vocabulary organization, content, structure, grammar, and spelling. Thus, they recommended using peer assessment for English writing courses and stated that it can be an effective and practical approach, leading students to constantly gain relevant knowledge and skills.

Jia, Chen, Ding and Ruan (2012) modified the open source course management system Moodle to build the individualized vocabulary analysis and assessment functions for English training. Through this blended learning environment, the students' performance in experimental group in the regular and specially vocabulary examinations improved gradually during the school term and was better than that of the control group. One of the implications of this study is that blended learning in English language classes with an individualized vocabulary acquisition and assessment system can make the students' performance improve in vocabulary acquisition and in regular examinations.

In another study, Kazu and Demirkol (2014) investigated the effect of the blended learning environment on high school students' academic achievement. At the end of this study, they concluded that the students who had studied in the blended learning environment were academically more successful than those who studied in a traditional learning environment.

More relevant to the current study, Al-Jarf (2007) studied the effect of blended learning on college readers. Significant differences were found between the experimental and control groups in their reading skills as measured by the posttest, proposing that reading achievement in the experimental group improved due to using online instruction. 
This means that the use of online instruction showed to be an effective tool to improve students' reading skills in English.

Iranian researchers have not ignored the topic of blended learning in their research studies. Soltani, Tehrani and Tabatabaei (2012) designed a study in order to determine the effect of blended online and face-to-face instruction on Iranian EFL learners' vocabulary achievement. The result of $t$ test between pretest and posttest showed a statistically significant difference between the experimental and control group regarding their vocabulary knowledge. The experimental group outperformed the control group.

Ghahari and Ameri-Golestan (2014) conducted a study investigating the impact of blended and classroom teaching methods on Iranian EFL learners' writing performance. The students in the experimental group received traditional methods of teaching writing along with learning through the web. Students in the control group, however, were taught by only the traditional teaching methods of writing and received the instructions, materials, and feedback just through traditional methods. The results of this study showed that using a blended teaching method can make a more desirable condition to improve the EFL learners' writing performance.

The effect of blended learning on reading comprehension was also investigated by Behjat, Yamini and Sadegh Bahjeri (2011). They assigned the participants in the control group to read printed texts outside the class whereas the experimental group participants were asked to visit a weblog after class to find their reading assignments. The researchers reported that reading materials on an e-tool like wikis encouraged reading as they had links and were editable, and learners could access them by just clicking on the underlined term or phrase to enter a new webpage, thus they had access to more reading resources. They concluded that reading encouraged learners' autonomy to read more materials independent of what was presented in the classroom.

\section{Methodology}

\section{A. Participants}

To meet the objectives of this study, 90 male and female intermediate learners of Safir language school, situated in the west of Tehran, were selected. They all had the experience of studying English for a minimum of one and half years in this Language School. First, Preliminary English Test (PET) was administered in order to homogenize the learners, then 60 learners out of 90 who scored between one standard deviation above and below the mean were selected and randomly assigned into two groups of 30 students labeled as experimental and control groups. Although assigning the participants in two groups was done randomly, there was no random sampling for choosing the subjects for participation in this study. The two groups took different teaching methods, that is, for the experimental group, blended learning was utilized while for the control group, a traditional method of teaching reading was used which was also utilized in the mainstream instruction of the language school.

\section{B. Instrumentation}

For the purpose of implementing this study, the following instrument was adopted which is described below:

The Preliminary English Test (PET), a language proficiency test designed for people who can use every day written and spoken English in intermediate level, was used in this study. This test is divided into four sections: Reading, Writing, Listening and Speaking. All sections were administered to homogenize the participants. As for the pretest and the posttest, only the reading section was administered.

\section{Research Design}

Considering the fact that the researchers ran a pretest for homogeneity beforehand, also there were two groups, and regarding the fact that sampling was not random but convenient; the design of this study was quasi-experimental. The researchers worked only with intermediate learners who were introduced by the institute and that is why random sampling was not possible. This study included one independent variable and one dependent variable. The dependent variable was reading proficiency and the independent variable was blended learning.

\section{Data Collection Procedure}

In this study, the participants consisted of 90 EFL learners out of whom 60 learners were chosen and assigned into two groups. Therefore, two classes of 30 learners were randomly selected as the experimental and control groups. Assigning each group as the experimental and control groups was done randomly.

The participants took part in the classes three times a week for ten sessions, each session lasted one hour and forty minutes. Furthermore, reading practices based on the reading activities of the textbook (American English File 3, by Clive Oxenden and Christina Latham-Koenig, first published in 1995 by Oxford University Press) were taught to both groups. The experimental group, however, received additional training in blended learning. The teacher posted a blog online after the lesson including a parallel reading comprehension, testing the learners' comprehension using the following techniques: Answering questions, summarizing, expressing reactions, matching concepts from the text, making predictions, generating questions, finding word roots, and more.

The learners in the experimental group were expected to do the reading tasks online and outside the class. Examples of the online material used in the treatment process are presented in appendix A. The topics for online reading were 
matched with the topics presented in the course book and in the reading comprehension exercises also taught to the control group. The learners were encouraged to discuss relevant topics online, or leave comments on the topics for asynchronous interaction through the internet.

At the end of the semester, the reading part of the PET was administered to examine the reading proficiency of both groups.

\section{RESUlts}

This study aimed at investigating the effect of blended learning on Iranian EFL learners' reading proficiency. To achieve this goal, the following research question was posed: Does blended learning have a statistically significant effect on Iranian EFL learners' reading proficiency?

The data were analyzed using independent samples and paired-samples $t$ test which assumes normality of the data which was met for the present data. As displayed in Table I, the ratios of skewness and kurtosis over their respective standard errors were within the ranges of $+/-1.96$.

TABLE I.

TESTING NORMALITY ASSUMPTION; PRETEST AND POSTTEST OF READING PROFICIENCY BY GROUPS

\begin{tabular}{|l|l|l|l|l|l|l|l|l|}
\hline \multirow{3}{*}{ Group } & $\mathrm{N}$ & \multicolumn{2}{l}{ Skewness } & \multicolumn{4}{l|}{ Kurtosis } \\
\cline { 3 - 9 } & Statistic & Statistic & Std. Error & Ratio & Statistic & Std. Error & Ratio \\
\hline \multirow{2}{*}{ Experimental } & Pretest & 30 & .135 & .427 & .316 & -1.142 & .833 & -1.37 \\
\cline { 2 - 9 } & Posttest & 30 & -.233 & .427 & -.545 & -.843 & .833 & -1.01 \\
\hline \multirow{2}{*}{ Control } & Pretest & 30 & .279 & .427 & .653 & -.445 & .833 & -.534 \\
\cline { 2 - 9 } & Posttest & 30 & -.095 & .427 & -.222 & -.339 & .833 & -.406 \\
\hline
\end{tabular}

The independent samples $t$ test has another assumption, which is the homogeneity of the variances of the groups which will be discussed when reporting the main results.

\section{A. Pretest of Reading Proficiency}

An independent $t$ test was run to compare the experimental and control groups' means on the pretest of reading proficiency in order to prove that they enjoyed the same level of reading proficiency prior to the main study. Based on the results displayed in Table II, it can be concluded that the experimental $(M=15.20, S D=3.15)$ and control $(M=$ $15.53, \mathrm{SD}=2.72$ ) groups had almost the same means on the pretest of reading proficiency.

TABLE II.

DESCRIPTIVE Statistics; PRETEST OF READING PROFICIENCY By Groups

\begin{tabular}{|l|l|l|l|l|l|}
\hline \multirow{2}{*}{} & Gender & $\mathrm{N}$ & Mean & Std. Deviation & Std. Error Mean \\
\hline \multirow{2}{*}{ Pretest } & Experimental & 30 & 15.20 & 3.156 & .576 \\
\cline { 2 - 7 } & Control & 30 & 15.53 & 2.726 & .498 \\
\hline
\end{tabular}

The results of the independent $t$ test $(\mathrm{t}(58)=.43, \mathrm{p}=.921, \mathrm{r}=.058$ representing a weak effect size) (Table III) indicated that there was not any significant difference between the two groups' means on the pretest of reading proficiency. Thus it can be claimed that they were at the same level of reading proficiency knowledge prior to the main study.

TABLE III.

INDEPENDENT SAMPLES T TEST, PRETEST OF READING PROFICIENCY BY GROUPS

\begin{tabular}{|c|c|c|c|c|c|c|c|c|c|}
\hline & \multicolumn{2}{|c|}{$\begin{array}{l}\text { Levene's Test for Equality of } \\
\text { Variances }\end{array}$} & \multicolumn{7}{|c|}{$t$ test for Equality of Means } \\
\hline & \multirow[t]{2}{*}{$F$} & \multirow[t]{2}{*}{ Sig. } & \multirow[t]{2}{*}{$\mathrm{T}$} & \multirow[t]{2}{*}{ Df } & \multirow{2}{*}{$\begin{array}{l}\text { Sig. }(2- \\
\text { tailed) }\end{array}$} & \multirow{2}{*}{$\begin{array}{l}\text { Mean } \\
\text { Difference }\end{array}$} & \multirow{2}{*}{$\begin{array}{l}\text { Std. Error } \\
\text { Difference }\end{array}$} & \multicolumn{2}{|c|}{$\begin{array}{l}95 \% \text { Confidence Interval of } \\
\text { the Difference }\end{array}$} \\
\hline & & & & & & & & Lower & Upper \\
\hline $\begin{array}{l}\text { Equal variances } \\
\text { assumed }\end{array}$ & 1.396 & .242 & .438 & 58 & .663 & .333 & .761 & -1.191 & 1.857 \\
\hline $\begin{array}{l}\text { Equal variances not } \\
\text { assumed }\end{array}$ & & & .438 & 56.799 & .663 & .333 & .761 & -1.191 & 1.858 \\
\hline
\end{tabular}

It should be noted that the assumption of homogeneity of variances was met (Levene's $F=1.39, p=.242$ ). That is why the first row of Table 4.3, i.e., "Equal variances assumed" was reported.

\section{B. Research Question}

Does blended learning have any statistically significant effect on Iranian EFL learners' reading proficiency?

An independent $t$ test was run to compare the experimental and control groups' means on the posttest of reading proficiency in order to probe the effect of the blended learning on the improvement of Iranian intermediate EFL learners' reading proficiency. Based on the results displayed in Table IV, it can be concluded that the experimental group $(M=17.93, S D=2.79)$ had a higher mean than the control $(M=16.40, S D=2.45)$ on the posttest of reading proficiency. 
TABLE IV.

DESCRIPTIVE STATISTICS; POSTTEST OF READING PROFICIENCY BY GROUPS

\begin{tabular}{|l|l|l|l|l|l|}
\hline \multirow{2}{*}{ Posttest } & Gender & N & Mean & Std. Deviation & Std. Error Mean \\
\cline { 2 - 6 } & Experimental & 30 & 17.93 & 2.791 & .510 \\
\cline { 2 - 6 } & Control & 30 & 16.40 & 2.458 & .449 \\
\hline
\end{tabular}

The results of the independent $t$ test $(\mathrm{t}(58)=2.25, \mathrm{p}=.028, \mathrm{r}=.28$ representing an almost moderate effect size $)$ (Table V) indicated that there was a significant difference between the two groups' means on the posttest of reading proficiency. Thus the null-hypothesis was rejected.

TABLE V.

INDEPENDENT SAMPLES T TEST, POSTTEST OF READING PROFICIENCY BY GROUPS

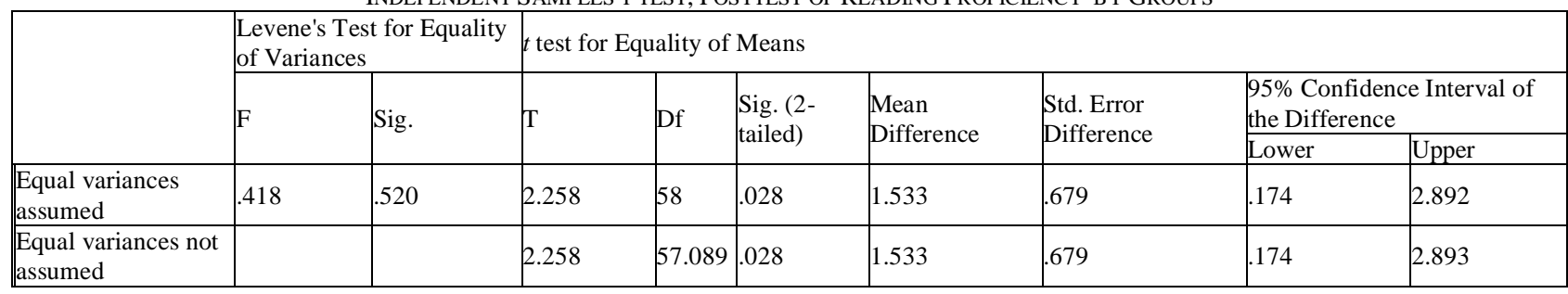

It should be noted that the assumption of homogeneity of variances was met (Levene's $\mathrm{F}=.41, \mathrm{p}=.52$ ). That is why the first row of Table V, i.e., "Equal variances assumed" was reported.

\section{KR-21 Reliability Indices}

The KR-21 reliability indices for the pretest and posttest of reading proficiency were 0.62 and 0.71 respectively.

TABLE VI.

\begin{tabular}{|l|l|l|l|l|}
\hline \multicolumn{7}{|c|}{ KR-21 RELIABILITY INDICES } \\
\hline Pretest & N & Mean & Variance & KR-21 \\
\hline Posttest & 60 & 15.37 & 8.575 & .62 \\
\hline
\end{tabular}

\section{Construct Validity}

A factor analysis was run through the varimax rotation to probe the underlying constructs of the pretest and posttest of reading proficiency. The SPSS extracted one factor which accounted for $91.75 \%$ (Table VII) of the total variance.

TABLE VII.

TOTAL VARIANCE EXPLAINED

\begin{tabular}{|l|l|l|l|l|l|l|}
\hline \multirow{2}{*}{ Component } & \multicolumn{3}{|l|}{ Initial Eigenvalues } & \multicolumn{3}{l|}{ Extraction Sums of Squared Loadings } \\
\cline { 2 - 7 } & Total & $\%$ of Variance & Cumulative \% & Total & $\%$ of Variance & Cumulative \% \\
\hline 1 & 1.835 & 91.751 & 91.751 & 1.835 & 91.751 & 91.751 \\
\hline 2 & 165 & 8.249 & 100.000 & & & \\
\hline
\end{tabular}

As displayed in Table 4.8, the pretest and posttest of reading proficiency loaded on the only extracted factor. Thus it can be claimed that they measured the same construct; i.e., reading proficiency.

TABLE VIII.

COMPONENT MATRIX

\begin{tabular}{|c|c|}
\hline \multirow{2}{*}{\multicolumn{2}{c|}{ COMPONENT MATRIX }} \\
\cline { 2 - 2 } & Component \\
\hline Posttest & 1 \\
\hline Pretest & .958 \\
\hline
\end{tabular}

\section{CONCLUSIONS}

The aim of this study was to determine the impact of blended learning on the reading proficiency of Iranian Intermediate EFL learners. The research question inquired whether blended learning has any statistically significant effect on Iranian EFL learners' reading proficiency. After running an independent $t$ test $(\mathrm{t}(58)=2.25, \mathrm{p}=.028, \mathrm{r}=.28)$ it was concluded that there was a significant difference between the two groups' means on the posttest of reading proficiency. This is while the means of the experimental group and the control group were not significantly different in the pretest. Therefore, the null-hypothesis was rejected and it was stated that blended learning has a significantly positive impact on the reading proficiency of Iranian EFL learners.

The findings of this study are in line with the findings of the study conducted by Al-Jarf (2007) and Ghahari and Ameri-Golestan (2014) who observed similar improvement in the reading proficiency of learners exposed to blended learning in comparison with those who studies reading in a traditional classroom setting. 
The results of this study can be adopted in the EFL classroom, as well as outside the class. EFL learners can improve their reading proficiency through blended learning as depicted in the present research and learners can also benefit from English language instruction at the place and time of their convenience without being deprived from the help of their teacher and while they are studying in a classroom setting at the same time.

The findings of the study also confirmed the results of the study of Kazu and Demirkol (2014) who reported a significant difference between learners' performance who attended traditional classrooms and those who learned in a blended learning environment, with the latter being more positively influential than the former. Similarly, Dowling, Godfrey and Gyles (2003) reported improved final marks and learning outcomes with blended learning.

In a similar line of research, Cameron (2003), Dziuban, Hartman and Moskal (2004), Dziuban, Hartman, Moskal, Sorg, and Truman (2004) and Dziuban, Hartman, Juge, Moskal, and Sorg (2005) discussed in separate studies that blended learning specifically enhances learner and teacher satisfaction as well as higher learner motivation. It may be the result of this higher level of satisfaction that has made blended learning more successful than traditional face-to-face classes in global research.

During the treatment of the experimental group in the present study, online discussions and interaction were also adopted in order to enhance the quality of the instruction. Accordingly, Garrison and Anderson (2003) shared the view that discourse is especially valuable in education and that asynchronous discussion is a very powerful learning strategy. The online discussions included in the blended learning material could be another factor contributing to the positive results achieved.

Based on the findings of the present study, the following pedagogical implications are discussed, firstly for the learners and secondly the teachers.

Blended learning can be adopted in the English language classes, in order to facilitate the learning process especially that of the reading skill. Learners can benefit from the advantages of blended learning as an accelerator of learning to read in second or foreign language in and outside the classroom. Blended learning, in this sense, can maximize the learning opportunities by happening at the place and time of the learner's choice. This may, in turn, further learner autonomy by giving more responsibility to the learner, thus moving away from traditional teacher-centered classes. Another positive outcome that may emerge as a result of employing blended learning in the English class is promoting motivation and interest in the language learning process on behalf of the learner. Learners can enjoy using technology and learn English and therefore associate the two as a positive, more desirable process.

The concept of blended learning can be introduced to EFL teachers who wish to improve their teaching skills and career and remain up-to-date with new technology and research findings. The positive influence of blended learning and its usage in the ELT field can be presented to teachers in Teacher Training or In-Service courses. As many teachers feel uncomfortable with adopting technology for teaching, the courses need to include methods and ideas supporting blended learning use as well as techniques and sufficient training in using the internet, social networks or different kinds of software to familiarize the teachers with the benefits of adopting a blended method to learning English.

EFL institutions and academic centers focusing on EFL education can also provide lesson plans and policies to incorporate blended learning into their syllabus and create an opportunity for improvement in their teaching regarding reading and perhaps other skills of English. Blended learning can also be presented and practiced at universities, especially for Teaching English as a Foreign or Second Language.

\section{APPENDIX. AN EXAMPle OF ONLINE READING MATERIAL}

\section{Example 1: The story of Coca Cola}

\section{The Story of Coca Cola \\ The most famous drink in the world}

What is the most recognizable object in the world? Could it be a football? Or a Big-Mac? No, the answer is a CocaCola bottle. The famous Coca-Cola bottle is almost 100 years old!

Footballs and big macs are certainly part of life for lots of people; but Coca-Cola is now a permanent part of world culture. People know and drink Coca-Cola all over the world.

It is said that the Coca-Cola bottle is the most recognised object in the world. Hundreds of millions of people can

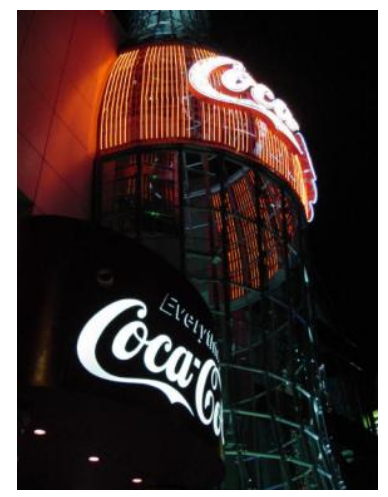
recognise a Coke bottle by its shape, even if they cannot see it! And the famous Coca-Cola logo is the most famous logo in the world. Unlike any other famous commercial logo, it has not changed in 100 years!

But the story of Coca-Cola is even older than that. It was in 1886 that John Pemberton, a druggist in Atlanta, Georgia, invented a new type of syrup, using coca leaves, sugar and cola nuts, plus a few other secret ingredients! Pemberton sold it as a medicine; and with its coca (the source of cocaine), it must have made people feel good!

Nevertheless, Pemberton's medicine was not very successful, so he sold his secret formula to another druggist, Asa Candler. Candler was interested, because he had another idea; he thought that Pemberton's "medicine" would be much better if it was mixed with soda.

Candler was thus the man who really invented the drink Coca-Cola. At first he sold it in 
his drugstore; then he began selling the syrup to other drugstores, who used it with their soda fountains. Candler also advertised his new drink, and soon people were going to drugstores just to get a drink of Coca-cola.

Before long, other people became interested in the product, including a couple of businessmen who wanted to sell it in bottles. Candler sold them a licence to bottle the drink, and very quickly the men became millionnaires. The famous bottle, with its very distinctive shape, was designed in 1916.

During the First World War, American soldiers in Europe began asking for Coca-Cola, so the Coca-cola company began to export to Europe. It was so popular with soldiers, that they then had to start bottling the drink in Europe.

Today, Coca-Cola is made in countries all over the world, including Russia and China; it is the world's most popular drink. As for the famous formula, it is probably the world's most valuable secret! The exact ingredients for making Coca-Cola are only known to a handful of people. And as for the "coca" that was in the original drink, it was eliminated in 1903. It was a drug, and too dangerous. Today's Coca-Cola contains caffeine, but not cocaine!

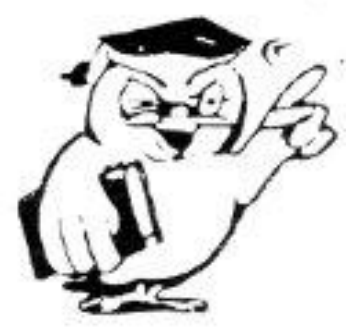

Words:

shape: form - logo: logotype, name-image - unlike : differently to - druggist: pharmacist - syrup: concentrated sweet drink - nuts: hard round fruits - ingredient: element - source: origin - formula: recipe, instructions for making something - soda: bubbling water, fizzy water - advertise: publicise - licence: permit, authorisation - distinctive: memorable, special - as for: concerning - a handful of: a very small number of - eliminate: take out -

\section{Work Sheet:}

Using information from the article, complete this résumé in your own words.

Coca Cola was _ by John Pemberton, a , and Pemberton sold it

Pemberton_ it in his drugstores, then he
first he to some businessmen,
the $\quad$ Write a summary of the article in 75 words.

living in Atlanta. The original drink was a medicine. It was really a decided to sell it the being made from coca drink, soda. At to drugstores. After that, he the drink. That was the of

\section{REFERENCES}

[1] Abisamra, N. S. (2009). Teaching language Reading: from an interactive perspective. Retrieved from website: www. Nadaislad.com/reading.

[2] Akkoyunlu B. \& M. Yilmaz Soylo. (2006). A study on students' views about blended learning environment, Turkish Online Journal of Distance Education 7.3, 43-56.

[3] Al-Jarf, R. (2007). Impact of blended learning on EFL college readers. In IADIS International Conference e-Learning, Lisbon.

[4] Behjat, F. \& M. Yamini and M. S. Bagheri. (2011). Blended Learning: A Ubiquitous Learning Environment for Reading Comprehension, International Journal of English Linguistics, 2.1, 97-106.

[5] Bersin, J. (2003). The Blended Learning Book: Best Practices, Proven Methodologies, and Lessons Learned, New York: Jossey-Bass/Pfeiffer.

[6] Cameron, B. (2003). The effectiveness of simulation in a hybrid and online networking course. TechTrends 47.5, 18-21.

[7] Chastain, K. (1988). Developing Second-Language Skills: Theory and Practice, 3rd ed., San Diego, CA: Harcourt Brace Jovanovich.

[8] Dowling, C. \& J. M. Godfrey and N. Gyles. (2003). Do hybrid flexible delivery teaching methods improve accounting students' learning outcomes? Accounting Education, 12.4, 373-391.

[9] Dziuban, C. \& J. Hartman \& P. Moskal. (2004). Blended learning, ECAR Research Bulletin, 7, 1-12.

[10] Dziuban, C. \& J. Hartman, P. Moskal, S. Sorg \& B. Truman. (2004). Three ALN modalities: An institutional perspective. In J. Bourne and J. C. Moore (eds.). Elements of Quality Online Education: Into the Mainstream, Needham, MA, Sloan Center for Online Education, 127-148.

[11] Dziuban, C. D. \& J. Hartman \& F. Juge, P. D. Moskal \& S. Sorg. (2005). Blended learning: Online learning enters the mainstream. In C. J. Bonk and C. Graham (eds). Handbook of Blended Learning Environment, San Francisco, CA, Pfeiffer Publications, 195-208.

[12] Garcia-Ruiz, M. E. (2005). Teaching Management Information Systems with Blended Learning Methods. In International Conference IADIS Multi, Cantabria.

[13] Garrison, D. R. \& T. Anderson. (2003). E-Learning in the 21st century: A framework or research and practice, London: Routledge/Falmer. 
[14] Ghahari S. \& A. Ameri-Golestan. (2014). The effect of blended learning vs. classroom learning techniques on Iranian EFL learners' writing. International Journal of Foreign Language Teaching and Research, 1.3, 1-9.

[15] Goodman, K. (1988). The Reading Process. In P. L. Carrell, J. Devine \& D. E. Eskey (eds.), Interactive Approaches to Second Language Reading. Cambridge: CUP, 11-21.

[16] Grabe, W. (1991). Current developments in second language reading research., TESOL Quarterly 25. 3, 375-406.

[17] Graham, C. R. (2006). Blended learning systems: Definition, current trends and future directions. In C. J. Bonk \& C. R. Graham (eds.), Handbook of blended learning: Global perspectives, local designs. San Francisco, CA: Pfeiffer Publishing, $120-135$.

[18] Jia, J. \& Y. Chen, Z. Ding \& M. Ruan. (2012). Effects of a vocabulary acquisition and assessment system on students' performance in a blended learning class for English subject, Computers and Education 58.1, 63-76.

[19] Kazu and I. Y. \& M. Demirkol (2014). Effect of Blended Learning Environment Model on High School Students' Academic Achievement. The Turkish Online Journal of Educational Technology 13.1, 78-87.

[20] Krashen, S. (1988). Second language acquisition and second language learning, Oxford: Pergamon.

[21] McGee P. \& A. Reis. (2012). Blended Course Design: A Synthesis of Best Practices, Journal of Asynchronous Learning Networks 16.4, 7-22.

[22] Osguthorpe R. T. \& C. R. Graham. (2003). Blended Learning Environments: Definitions and Directions. Quarterly Review of Distance Education 4.3, 227-233.

[23] Richards C. J. \& R. Schmidt, Longman Dictionary of Language Teaching and Applied Linguistics, London: Pearson Education, 2002.

[24] Rivers, W. M. (1968). Teaching foreign-language skills, (2nd ed.). Chicago: The University of Chicago Press.

[25] Rumelhart, D. E. (1977). Toward an interactive model of reading. In S. Dornic (ed.), Attention and Performance (vol. 4), New Jersey: Lawrence Erlbaum Associates, 573-603.

[26] Shih, R. C. (2011). Can Web 2.0 technology assist college students in learning English writing? Integrating Facebook and peer assessment with blended learning, Australasian Journal of Educational Technology 27.5, 829-845.

[27] Soltani Tehrani N. \& O. Tabatabaei. (2012). The Impact of Blended Online Learning on Iranian EFL Learners' Vocabulary Achievement. International Electronic Journal for the Teachers of English, 2.5, 73-88.

[28] Thorne, K. (2003). Blended Learning: How to Integrate Online and Traditional Learning, London: Kogan Page Limited.

Tina Ghazizadeh was born in 1988 in Tehran. She did her BA in English literature at Islamic Azad University of Parand, Tehran, Iran, in 2010 and her MA in Teaching English as a Foreign Language at Roudehen Islamic Azad University, Tehran, Iran, in 2015. She has worked as an English teacher in Safir Language Institute since 2007.

Hamidreza Fatemipour (Corresponding Author) graduated in English language teaching (Ph.D. degree) from Panjab University, Chandigarh, India in 2008. He is an Assistant Professor in the Department of ELT, Islamic Azad University, Roudehen Branch, Roudehen, Iran. He was the Dean of the Faculty of Persian Literature and Foreign Languages, IAU, Roudehen Branch from 2009 to 2015. He has been the Vice-Chancellor for Education, IAU, Roudehen Branch since 2015. His research interests are CLIL, CALL, and Reflective Teaching. Dr. Fatemipour was one of the authors of the book, entitled "Read the Press". Tehran, Iran: Shokoh-eAndisheh, 2005. He published twelve papers in different Journals and presented ten papers in international conferences in Iran, Spain, Japan, and Belgium. Dr. Fatemipour is a member of TELLSI, Teaching English Language and Literature Society of Iran. 